\title{
J. Wentzel van Huyssteen: Exploring Venues for Interdisciplinary Theology
}

Gregersen, Niels Henrik

Published in:

Theology Today

DOI:

$10.1177 / 0040573615581547$

Publication date:

2015

Citation for published version (APA):

Gregersen, N. H. (2015). J. Wentzel van Huyssteen: Exploring Venues for Interdisciplinary Theology. Theology Today, 72(2), 141-159. [1]. https://doi.org/10.1177/0040573615581547 
J. Wentzel van Huyssteen: Exploring Venues for an Interdisciplinary Theology
2015, Vol. 72(2) 141-159

(C) The Author(s) 2015

Reprints and permissions: sagepub.co.uk/journalsPermissions.nav DOI: I0.1 I77/00405736/558|547 ttj.sagepub.com

\title{
Niels Henrik Gregersen
}

University of Copenhagen

\begin{abstract}
This article, written for the retirement symposium for the James I. McCord Professor J. Wentzel van Huyssteen at Princeton Theological Seminary ("Evolutionary Science and Theological Identity," November 18-19, 2014), analyzes the changing contexts and developments of van Huyssteen's interdisciplinary journeys in the philosophy of science, epistemology, and science and religion. The topics discussed are biblical hermeneutics, his relation to Wolfhart Pannenberg, critical realism, postfoundationalism, evolutionary epistemology, paleoanthropology, and theological anthropology. The particular aim of the article is to clarify how earlier research themes are transformed and calibrated in van Huyssteen's shift of emphasis from a more hermeneutical to a more pragmatist orientation in interdisciplinary theology.
\end{abstract}

\section{Keywords}

J. Wentzel van Huyssteen, critical realism, postfoundationalism, pragmatism, evolutionary epistemology, paleoanthropology

The aim of this article is to trace central lineages in J. Wentzel van Huyssteen's academic and spiritual journey in interdisciplinary theology. I'm not the first to do so. Van Huyssteen's oeuvre has already been discussed in a number of special journal issues, and even in a doctoral dissertation. ${ }^{1}$ In the Festschrift in honor of his 65th birthday, Kenneth A. Reynhout offers a comprehensive presentation of

1. Including Zygon: Journal of Religion and Science 32(4) (1997) and 43(2) (2008); American Journal of Theology \& Philosophy 28(3) (2007), and Toronto Journal of Theology 26(2) (2010). See also G.M.H. Loubser, 'A Public Theologian: A Critical Study of J. Wentzel van Huyssteen's Postfoundationalist Facilitation of Interdisciplinarity' (doctoral dissertation, Stellenbosch University, 2012), accessible at http://hdl.handle.net/10019.1/20169.

\section{Corresponding author:}

Niels Henrik Gregersen, University of Copenhagen, Koebmagergade 44-46, Copenhagen, I I 50 K, Denmark. Email: nhg@teol.ku.dk 
van Huyssteen's work, probably the best to date. Reynhout distinguishes between a first phase, "critical realism as rationality model for theology" (1970-1989), a second phase on "the interdisciplinary shaping of rationality in a postmodern context" (1990-1999), and a third phase on "the evolutionary origins of rationality and human uniqueness" (2000-present). ${ }^{2}$

In what follows, my focus will be less on van Huyssteen's chronological development and more on the different locations and intellectual venues for his interdisciplinary theology. Van Huyssteen has undertaken a remarkable journey in his life and career. His homeland was and remains South Africa. As is evident from his "Introduction" to Essays in Postfoundationalist Theology (the first book he published after he moved to Princeton), he is acutely aware of the role of geography and place, not least with respect to the half-globe distance between Port Elizabeth and Princeton. ${ }^{3}$ There is a difference between lecturing, say, at the Highlands Institute for American Religious and Philosophical Thought (since 2012, Institute for American Religious and Philosophical Thought) and at Princeton Theological Seminary. And again it is different to lecture in Canada and Korea, on the European Continent and in the UK. Nonetheless, Wentzel van Huyssteen's style of reasoning is remarkably consistent from beginning to end, focused on elaborating an interdisciplinary view of human rationality and theology, in particular for the field of science and religion.

\section{The home venue: South Africa}

Let me begin with van Huysteen's own beginnings in his South African context. There is here much of which I only know by hearsay, such as his time as minister in the Dutch Reformed Church (1971-1972), followed by his appointment as Professor and Head of the Department of Religious Studies at the University of Port Elizabeth (1972-1991). Let me remind of his early engagement with body phenomenology in his M.A. on "Truth and Relativism in the Thought of Maurice Merleau-Ponty" (1966). This indicates an influence from an interactionist phenomenology in his early education, which in fact resurfaces in later work, for example in his 2006 article "When Our Bodies Do the Thinking, Theology and Science Converge," where the "patterns of our daily experience" are seen as the

2. Kenneth A. Reynhout, "The Evolution of van Huyssteen's Model of Rationality," in The Evolution of Rationality. Interdisciplinary Essays in Honor of J. Wentzel van Huyssteen, ed. F. Leron Shults (Grand Rapids: Eerdmans, 2006), 1-18. In the same volume, I offered my account of the development of van Huyssteen's work, especially within the first and second phase: "What Theology Might Learn (and Not Learn) from Evolutionary Psychology: A Postfoundationalist Theologian in Conversation with Pascal Boyer," 306-26, esp. 307-11. Some observations from this article are expanded upon below.

3. J. Wentzel van Huyssteen, "Introduction," in Essays in Postfoundationalist Theology (Grand Rapids: Eerdmans, 1997), 1-8 (1). 
inevitable entry point for interdisciplinary thinking. ${ }^{4}$ No wonder, therefore, that Merleau-Ponty's work comes up again in the Gifford Lectures, and in van Huyssteen's later interaction with Maxine Sheets-Johnstone's phenomenology of body movement. ${ }^{5}$

In his intellectual baggage from South Africa the role of hermeneutics is perspicuous, as evidenced in the Powell Lectures that he delivered at the University of South Africa in 1987. There he argues that biblical authority should not be appealed to as a discussion stopper, but rather be seen a primary resource for how Christians come to terms with reality. The focus is on what he calls "the quality of the biblical text," including its continuous "referential power" for Christians using the biblical text as a "way to God." hermeneutical reader-response perspective, informed by the work of James Barr and Paul Ricoeur. As a systematic theologian van Huyssteen is thus interested in

the reader's actions involved in responding to the biblical text. This text (1) evokes religious experience, (2) implies ontological commitment, and (3) provides, through the metaphorical nature of the central concepts of biblical language, a striking continuity of reference in the history of Christian thought. ${ }^{7}$

By ascribing to a reader-response perspective (as early as 1987), van Huyssteen argues against a biblical literalism while also guarding himself against the opposite danger that the Bible is read at the mercy of a pure relativism: "The role of the reader can, however, never be pressed in such a way as to imply an infinite relativism on the part of the text or its authority." 8 The text has a reality of its own, one may say, which is then used to illuminate the world in front of us. ${ }^{9}$

4. J. Wentzel van Huyssteen, "When Our Bodies Do the Thinking, Theology and Science Converge," American Journal of Theology \& Philosophy 27(2-3) (2006): 127-53 (153). See also below with reference to the Gifford Lectures.

5. J. Wentzel van Huyssteen, "Should Theology Take Evolutionary Ethics Seriously? A Conversation with Hannah Arendt and Maxine Sheets-Johnstone," NGTT 54(3-4) (2013), 275-85.

6. J. Wentzel van Huyssteen, "The Realism of the Text: A Perspective on Biblical Authority," in Essays in Postfoundationalist Theology (Grand Rapids: Eerdmans, 1997), 124-61 (158-60), italics in original. Later, in his Gifford Lectures, he speaks of the biblical texts as having a "gravitational force," or "pull," a power of attraction mediated by the reception history; see Alone in the World? Human Uniqueness in Science and Theology. The Gifford Lectures. The University of Edinburgh. Spring 2004 (Grand Rapids: Eerdmans, 2006), 115: "a canon, as a complex but identifiable core identity, and as embodying a rich galaxy of meanings, thus has gravitational force, or a gravitational pull that is the result of the way its own internal structure relates to and is construed in the always plural history of its interpretative relations."

7. Van Huyssteen, "The Realism of the Text," 151.

8. Ibid., 148.

9. As phrased by Paul Ricoeur: "To interpret is to explicate the type of being-in-the-world unfolded in front of the text"; see Ricoeur, "The Hermeneutical Function of Distantiation," in Hermeneutics and the Human Sciences: Essays on Language, Action, and Interpretation, ed. John B. Thompson (Cambridge: Cambridge University, 1981), 131-44 (141). 
In his early lectures on biblical hermeneutics, van Huyssteen is already referring to science-religion discussions. The natural sciences should not necessarily "be regarded as the paradigm for what constitutes reliable knowledge." 10 The future program of postfoundationalism was here in the making, though still couched mainly in the framework of critical realism. But also later, when the postfoundationalist view was in place, as in the John Albert Hall Lectures given at the University of Victoria, Canada, published as Duet or Duel? Theology and Science in the Postmodern World in 1998, van Huyssteen emphasized the "semantic surplus" of theology in relation to science, thus arguing that

the theological redescription of the world, therefore, can never be merely a mirroring of the world of science. It is always, rather, a complementary view in which the very special epistemological focus, distinct experiential dimension and heuristic apparatus of theological reflection creatively illuminate not only the world of science, but also the wider world around it. ${ }^{11}$

From one perspective, our scientific understanding of the world is capable of both constraining and expanding views of reality offered by theology, but on the other hand, theology has many other epistemic resources by addressing aspects of reality in which the natural sciences have no particular interest. Accordingly, theology is not to be described as a causal explanation in conflict with scientific explanations, but rather as a complementary interaction with reality. One thing is causal explanation; another thing is semantic explanation, that is, hermeneutical explication. There remains a hermeneutical basis for all theological reasoning, though the questions of ontological truth claims cannot be replaced by the reading of classic texts of tradition: "[A]ll systematic theology may be said to be basically interpretative or hermeneutical, but then hermeneutical in a sense that concerns not only meaning but also the question of truth." 12 Certainly, van Huyssteen does not want to succumb to the "pan-linguistic folly" of some current strands of hermeneutical philosophy and deconstructive postmodernism. ${ }^{13}$

\section{Between Amsterdam and Munich: the interaction with Wolfhart Pannenberg}

The doctoral dissertation on "Rationality and Faith in the Thought of Wolfhart Pannenberg" (in Dutch, 1970) was based on studies at the Free University of

10. Van Huyssteen, "The Realism of the Text," 127; italics in original.

11. J. Wentzel van Huyssteen, Duet or Duel? Theology and Science in the Postmodern World (London: SCM Press, 1998), 161; cf. 126.

12. J. Wentzel van Huyssteen, Theology and the Justification of Faith: Constructing Theories in Systematic Theology, trans. H.F. Snijders (Grand Rapids: Eerdmans, 1989; Dutch, 1986), 171.

13. J. Wentzel van Huyssteen, "Response to Critics," American Journal of Theology \& Philosophy 28(3) (2007): 409-32 (431-32). 
Amsterdam 1966-1970, and a longer stay at Ludwig Maximilian University of Munich during 1969. Observe that the topic was here not on the rationality of theology per se, but the relation between rationality and faith. Whenever van Huyssteen speaks about epistemology, there is always an undercurrent of firstorder religious commitments involved. One would not do justice to van Huyssteen's program in saying that we have faith commitments as a first-order phenomenon, then systematic theology as a second-order reflection of religious experience, and then epistemology as a third-level reflection, staying aloof, as it were, from first-order commitments. Rather, from beginning to end, van Huyssteen's program for a postfoundationalist epistemology emphasizes "the high degree of personal commitment in religious and theological theorizing.",14 While not shying away from taking an intellectual stance to faith commitments as part of a philosophical self-reflection, van Huyssteen underlines that we are never decontextualized human beings. Human beings are human persons, and human persons are both embodied and socially embedded. Therefore, it is finally not propositions that are rational or irrational, but human persons are rational, insofar as they give reasons for their stance in communication with others.

This personal orientation comes fully to the fore in van Huyssteen's critical questions to Wolfhart Pannenberg. In many ways, van Huyssteen's later Theology and the Justification of Faith from 1989 is an updated work in line with Pannenberg's Wissenschaftstheorie und Theologie from 1973. Here van Huyssteen won his "street cred" in science and religion by working through distinctive developments of the contemporary philosophy of science-from the Vienna School through Karl Popper and Imre Lakatos to Thomas Kuhn and Larry Laudan. In contrast to Pannenberg, however, van Huyssteen also focused on the question of the role of metaphors in theological language when presenting his version of a critical realism within theology.

Accordingly, there are some particular signatures to van Huyssteen's critical interaction with Pannenberg. First, whereas Pannenberg speaks about theology as a hypothesis of God capable of covering all relevant data, van Huyssteen translates Pannenberg as implying that a theology has proved itself "if it has succeeded in maximally solving and meaningfully integrating problematic data and mankind's experiences of reality." 15 This emphasis on problem-solving and experiential meaning can, with hindsight, be seen as a more pragmatic orientation of van Huyssteen's work. A few years later, van Huyssteen is translating Pannenberg's emphasis on theological propositions and "statements" into "convictions." 16 Accordingly he asks Pannenberg the following question: "At this stage we may begin to pose a central critical question to Pannenberg: How does he justify his view of the role of the theologian's personal religious commitment in the process of theorizing in

14. Van Huyssteen, Essays in Postfoundationalist Theology, 6.

15. Van Huyssteen, Theology and the Justification of Faith, 95.

16. Van Huyssteen, "Truth and Commitment in Theology and Science: A Critical Appraisal of Wolfhart Pannenberg's Perspective" (1989), Essays in Postfoundationalist Theology, 53-72 (59). 
theology, and his definition of truth and objectivity in theology and science?" 17 This question, if I understand it correctly, is not merely an amendment to Pannenberg's program of theology, but a question about its foundations. Whereas for Pannenberg the idea of God - as a statement about something - is kept "distinct from the person who makes that statement," van Huyssteen's order goes the other way around, from personal convictions to theological statements. ${ }^{18}$ This is not an innocent reversal of order, since van Huyssteen eventually questions the distinction between "the context of discovery" and "the context of justification" so central to Karl Popper's (and Imre Lakatos's) philosophy of science. Accordingly, he asks "whether personal faith - which operates in 'the context of discovery' - can really be separated from the theoretical context of justification. Why not consciously allow for the accounting of this subjective element from the outset in one's method?"19 In other words, the level of the explanans and the level of the explanandum cannot be cleanly separated. Religious interpretation is always self-involving, whereby the explainer him- or herself becomes part of what is to be explained. Human beings are, to use a phrase of Charles Taylor's, "self-interpreting animals.",20

\section{Critical realism: entering the Anglo-American dialogue of science and religion}

When writing Theology and the Justification of Faith, van Huyssteen hardly had at hand a fully satisfying model for dealing with the role of the personal commitments and social embedment in theology. What he had at his disposal was a "criticalrealist perspective," by which he situated himself in the Anglo-American discussion on science and religion. ${ }^{21}$ Against the trend of postliberal theology, for example in George Lindbeck, van Huyssteen insists that religious experience is and remains an indispensable background for theology, not replaceable by a Wittgensteinian emphasis on the cultural-linguistic performances within the church. As a matter of fact, "people grapple with religious experience also outside established denominations, and therefore the theologian is functioning contextually also by defining and attempting to solve valid problems outside existing churches." 22 First, the reality depiction of second-order theological statements presupposes the claims of first-order religious commitments: "At the basis of the reasons for using this term [of critical realism] is the conviction that what we are provisionally

17. Ibid., 58, italics in original.

18. Van Huyssteen, "Systematic Theology and Philosophy of Science: The Need for Methodological and Theoretical Clarity in Theology" (1981), Essays in Postfoundationalist Theology, 105-23 (119).

19. Ibid., 122.

20. Charles Taylor, "Self-interpreting Animals," in Philosophical Papers Vol 1: Human Agency and Language (Cambridge: Cambridge University, 1985), 45-76.

21. Essays in Postfoundationalist Theology, 125-77.

22. Ibid., 166. 
conceptualizing in theology really exists." 23 Second, van Huyssteen makes clear that theological statements rest on a fluid network of religious metaphors and models, which are not fully translatable into theoretical statements but rather have an explorative nature:

we are not simply describing realities that are equally accessible by other means. Language does not merely represent or reflect reality; it also constitutes reality. In this sense metaphoric language opens up to us, both creatively and exploratively, the reality of which we speak, since what we see as reality is to a large extent creatively and exploratively determined by the metaphoric potential of the language in which reality is depicted. ${ }^{24}$

Third, van Huyssteen is keenly aware that the feature of a "convergent realism" in some of the mature sciences (for example, geology reaching still better approximations to the movements of tectonic plates) is "virtually impossible" in theology; with Ernan McMullin he is worried of a too direct move from scientific realism to a critical realism in theology: "I think that anyone considering the possibilities of scientific realism for theology should be extremely wary of an uncritical, superficial transferring of the realism of science to the domain of religious belief, and to theology as the reflection on the claims of this belief.", 25

Here again, the hermeneutical character of van Huyssteen's argument comes to the fore. Theology only refers to divine reality in the context of linguistic networks that open up possibilities of human engagement with divinity. Accordingly, theological models and metaphors are redescribing the world(s) of nature as already (partly) described and (partly) explained by the sciences. ${ }^{26}$ This hermeneutical $^{2}$

23. Van Huyssteen, Theology and the Justification of Faith, 155 (emphasis mine). Van Huyssteen's early position is presented in condensed form in "Experience and Explanation: The Justification of Cognitive Claims in Theology" (1988), Essays in Postfoundationalist Theology, 162-79; the author points out that he is only willing to argue "for a qualified and weak form of critical realism" (167), insofar as the referential claims are derived from "basic assumption and good reasons," without the reasons being conclusive, and without the claim of a progressively convergent realism. See also my article, "Critical Realism and Other Realisms," in Fifty Years in Science and Theology: Ian G. Barbour and His Legacy, ed. Robert J. Russell (Aldershot: Ashgate 2004), 77-96.

24. Van Huyssteen, Theology and the Justification of Faith, 137-38.

25. Ibid., 150, 155. See also Fabio Gironi, "The Theological Hijacking of Realism: Critical Realism in 'Science and Religion'," Journal of Critical Realism 11(1) (2012): 40-75. Gironi wrongly presupposes that when theologians such as van Huyssteen refer to the reality of God, they slip in "a Reality at the top (or at the base) of the order of being, well beyond both the human and the natural ontological stratum" (48-49). If God is the infinite or encompassing Reality, there is no such natural-supernatural dichotomy.

26. The concept of "redescription" only comes up occasionally in Theology and the Justification of Faith (e.g. p. 157), but attains a central role in J. Wentzel van Huyssteen, Duet or Duel?, 125-28, 160-64. Van Huyssteen kindly refers to my insistence that the role of offering causal explanations and the task of giving semantic explanation should not be conflated. The term "redescription," by the way, has its provenance in Donald Davidson's concept of "radical interpretation," where no formal translation schemes exist. 
orientation may also explain why van Huyssteen never followed otherwise popular attempts to apply Imre Lakotos's model of rationality to the justification of religious truth claims. ${ }^{27}$ The realism, in other words, is not between words and things (as if they were two quite different areas), but applies to structures - in theology to the relations between God and humanity or world, as apprehended by religious interpreters. Here there is a similarity to the basic realist claim that also "the scientist is in a creative way discovering the structures of the world." 28

This critical realism was seriously transformed in the wake of van Huyssteen's later pragmatist orientation. Seen from the postfoundational perspective, realism "does not represent a discovered fact or a justified position, but rather the methodological presupposition of our praxis of inquiry." 29 The realism is thus a presupposition undergirding the multiple interactions of the believer with worldly realities, when speaking of the encompassing reality of God. Since there is no strict dichotomy between the 'natural' and the 'supernatural,' no reductionist choice should be made between scientific and theological descriptions of reality. ${ }^{30}$

\section{Princeton: a new habitat for interdisciplinary theology}

Princeton became and remains the second home for Wentzel and Hester van Huyssteen. Preceded by a fellowship at the Center of Theological Inquiry in 1990, van Huyssteen came to Princeton Theological Seminary January 1, 1992 as the inaugural holder of the James I. McCord professorship in theology and science. At PTS he found a fertile collegial work space which allowed him to teach science and religion courses continuously, to put the books he wanted to work with on the curricula, and to discuss them intensely with the excellent students at the seminary. "Always work with the best and newest literature in the field" became his working motto, as also revealed in his many interactions with contemporary scientists and philosophers. Any reader is therefore well educated through van Huyssteen's essays, resulting from the sometimes hectic lecture program of the new Princetonian. In fact, Princeton Theological Seminary not only served as a home base, but also as an open door to the outside world - not only to AAR and the

27. See van Huyssteen's criticism of Nancey Murphy's bold work in her Theology in an Age of Scientific Reasoning (Ithaca: Cornell, 1990), in "Is the Postmodernist Always a Postfoundationalist? Nancey Murphy's Lakatosian Model for Theology," Theology Today 50(3) (1993): 373-86, reprinted in Essays in Postfoundationalist Theology, 73-90.

28. Theology and the Justification of Faith, 151 (with reference to Ernan McMullin).

29. See his "Postfoundationalism in Theology and Science," in Rethinking Theology and Science: Six Models for the Current Dialogue, ed. Niels Henrik Gregersen and J. Wentzel van Huyssteen (Grand Rapids: Eerdmans, 1998), 13-50 (39). Or as put in Nicholas Rescher's terms, "realism is a position to which we are constrained not by the push of evidence, but by the pull of purpose" (50, italics in original).

30. J. Wentzel van Huyssteen, "Pluralism and Interdisciplinarity: In Search of Theology's Public Voice," American Journal of Theology \& Philosophy 22(1) (2001): 65-87 (78). 
Highlands Institute, but also to the creative triangle between Princeton, Scotland, and Seoul, and to many Canadian and European audiences.

Already the inaugural lecture for the James I. McCord chair, "Theology and Science: The Quest for a New Apologetics," revealed many of the topics to be developed in the coming years. "The question how theology and science should relate to one another is, of course, neither a theological nor a scientific issue. It is, rather, an epistemological issue, that is, an issue about how two very different claims to knowledge are to be related." 31 With Philip Clayton, van Huyssteen pointed to the "contextualist shift" in the contemporary philosophy of the natural sciences, where the search for explanation and intelligibility is "relativized and become an element within the broader hermeneutical task of science.",32 Also the distinction between personal, communal, and transcommunal explanations comes up in the inaugural lecture, the latter offering news ways of articulating the theological tradition of apologetics and natural theology in a contemporary context. ${ }^{33}$ Even the term "the shaping of rationality" is announced, later to become the title of his main work in epistemology, The Shaping of Rationality from 1999.

The program of a postfoundationalist theology earlier announced was refined and presented in a fuller scale in The Shaping of Rationality: Toward Interdisciplinarity in Theology and Science. As rightly observed by Josh Reeves, van Huyssteen here uses both a negative and a positive strategy in defining the space for postfoundationalism. ${ }^{34}$ The negative strategy is to show that both foundationalism and nonfoundationalism fail - the first by discouraging conversation by reference to the safe haven of scientific evidence, the latter by referring to the safe heaven of establishing holistic webs of beliefs, such as in narrative theology. The positive strategy is to show that postfoundationalism steers a middle course by offering the best from the worlds of modernity and postmodernity. For example: accept science for what it is, the best bets we have for understanding the structure of the universe and evolution of life and humanity. But also: acknowledge that rationality remains person- and situation-relative, always undergirded by a flexible use of common-sense deliberations, reaping from many resources of human experience.

In The Shaping of Rationality from 1999, van Huyssteen re-emphasized the earlier hermeneutical orientation, while giving hermeneutical interpretation a pragmatist twist. The hermeneutical orientation was retained insofar as he continues to underline the pre-theoretical character of rationality while pointing to the

31. J. Wentzel van Huyssteen, "Theology and Science: The Quest for a New Apologetics" (1993), Essays in Postfoundationalist Theology, 215-37 (221).

32. Ibid., 232.

33. Ibid. 232, 234.

34. Josh Reeves, "Problems for Postfoundationalists: Evaluating J. Wentzel van Huyssteen's Interdisciplinary Theory of Rationality," The Journal of Religion 93(2) (2013): 131-50. 
formative role of traditions as "boundaries of our habitations." 35 Traditions are inescapable as our epistemic starting points - they are the boundaries from which we address the world. But traditions are not inevitably our final destination-we can both extend our traditions by entering into trans-communal dialogues and also take leave of traditions, even if we continue to be marked by them. ${ }^{36}$

The new pragmatist orientation implies that rationality no longer resides first and foremost in the capacity to open up interpretative horizons, but in the capacity of rational agents to form responsible judgments and seek optimal understandings, given the specific context and the specific problems to be solved. Human rationality is indeed humane.

There are several philosophical inspirations behind this shift of orientation in van Huyssteen's work. ${ }^{37}$ The first name to be mentioned is probably Nicholas Rescher, from whom van Huyssteen learned to speak of the dimensions of rationality. Alongside the cognitive dimension we have the evaluative and the pragmatic dimensions which correspond to the human pursuit of values and appropriate action. With Rescher, van Huyssteen regards science as the prime case for the cognitive pursuit of truth, while insisting that scientific rationality is just one subset of rationality at work. ${ }^{38}$ Accordingly, philosophers and theologians must learn to acquire what Rescher calls a "dissensus tolerance" between the different forms of reasoning, each proper for different and distinctive purposes. ${ }^{39}$ Finally from Rescher comes the view that any "theoretical cycle" of argumentation is to be accompanied by an "applicative cycle" of real-life implementation, which finally determines the fertility of our leading ideas, hence deciding about their feasibility. $^{40}$

Another source of inspiration is Harold Brown's theory of rationality that led van Huyssteen to see the concept of rational beliefs to be derivative to the reasoning of agents, who are making the rational estimates about truth, values, and

35. See J. Wentzel van Huyssteen, The Shaping of Rationality: Toward Interdisciplinarity in Theology and Science (Grand Rapids: Eerdmans 1999), 252-59, where he (following Delwin Brown, Boundaries of Our Habitations: Tradition and Theological Construction [New York: SUNY Press, 1994]) discusses how rational self-reflection is shaped by traditions without being tied up with unnegotiable truth claims.

36. See further "When Our Bodies Do the Thinking," 141-46, esp. 143.

37. Again, this pragmatic orientation is anticipated in van Huyssteen's early reception of Larry Laudan's work in Theology and the Justification of Faith, 172-90.

38. Van Huyssteen, Essays in Postfoundationalist Theology, 246-47; The Shaping of Rationality, 12829, 162: "I think, the selection of science as our clearest example of the cognitive/theoretical dimension of rationality at work is indeed justified. What is not justified, however, is any claim for the superiority of scientific rationality, and any attempt to extend uncritically the nature of a strictly scientific rationality to the rationality of religious or any other reflection." Cf. Nicholas Rescher, Rationality (Oxford: Clarendon, 1988).

39. "When Our Bodies Do the Thinking," 150.

40. Nicholas Rescher, A System of Pragmatic Idealism. Volume 1: Human Knowledge in Idealistic Perspective (Princeton: Princeton University, 1992), 175. 
adequate behavior. ${ }^{41}$ Rationality is not only a general capacity, but an "epistemic skill" to be learned, in analogy to physical skills.

Finally, Calvin Schrag had used the term "transversal rationality" to describe the fact that rationality is not domain-specific but emerges in the intersection, crossing-over, or interweaving of forms of rational discernment in different areas of life-from the sciences to religion and everyday practices. ${ }^{42}$ In a sense, this openended transversality replaces the modernist concept of unrestricted universality. ${ }^{43}$

Interestingly, the concept of transversality itself goes back to Jean-Paul Sartre's concept of the intersection of intentionalities, by which past experiences are retained in ever new intentional acts of the I. Sometimes I have been wondering, What would have happened if van Huyssteen had written out the phenomenological insights undergirding his epistemological reflections? Anyway, the comprehensive view of rationality that van Huyssteen develops from beginning to end accentuates that rational agents are always embedded in communicative contexts, in which agents have to account for their views while taking issues with the best candidates on the market of rational ideas, and having to apply these ideas in real life contexts. On the one hand, there exists no solitary epistemological subject à la Kant (but only contextually situated individuals). On the other hand, rational procedures guide our behavior, even where we have no foundational starting points available. Our steps forward cannot be controlled by following rules set up prior to our walking.

In consequence, the dialogue between science and religion shows different aspects of contact. There are shared resources of rationality between theology and the sciences (for example, logic and the search for order and intelligibility). There are overlapping elements of rationality (such as the role of models and metaphors in theorizing, and our realist instincts guiding our search for truth). Finally, we have very distinctive forms of rationality that cannot easily be transferred from one discipline to another. Mathematical equations in science, for example, have no counterpart in theological rationality, whereas the search for meaning, value, and existential relevance in theology has no immediate analogue in the proper sciences (though, perhaps, in popular science). ${ }^{44}$

\section{Was van Huyssteen ever a postmodernist?}

While distancing himself from the relativistic versions of postmodernism, there should be no doubt that during the 1990s van Huyssteen felt postmodernism as

41. Van Huyssteen, Essays in Postfoundationalist Theology, 247-54; The Shaping of Rationality, 14250. Cf. Harold Brown, Rationality (London: Routledge 1990).

42. Van Huyssteen, The Shaping of Rationality, 132-39. Cf. Calvin O. Schrag, The Resources of Rationality: A Response to the Postmodern Challenge (Bloomington: Indiana University 1992), and especially, "Transversal Rationality," in The Question of Hermeneutics, ed. T.J. Stapleton (Amsterdam: Kluwer, 1994).

43. "When Our Bodies Do the Thinking," 137; cf. 140: "transversality ultimately replaces universality."

44. Van Huyssteen, Duet or Duel?, 160-66. 
a liberation from the imprisonment under too abstract notions of rationality. "In a postfoundationalist epistemology the modernist distinction between 'objective' empirical (read: scientific) reasons and more 'subjective' ethical, religious, or aesthetic reasons is revealed as nonsensical." 45 Accordingly, he was seen by many (perhaps even by himself at that time?) as a postmodernist thinker. I must admit that I sometimes asked myself at that time, Are the cognitive contents of theology and the empirical elements of scientific reasoning taken sufficiently seriously in the wake of Wentzel's pragmatist turn and postmodern leanings? In the fall of 1996 when we together wrote the introduction to our co-edited book, Rethinking Theology and Science, we agreed upon using the term "cognitive pluralism" as a description of the postmodern situation rather than seeing postmodernism as a normative concept in contrast to modernism.

Those fearing in those days that van Huyssteen was about to go down the slope of postmodernism should be aware that for him the discourse of postmodernity remains in contact with modernity, just as the discourses of modernity remain within the web of postmodern discourse. ${ }^{46}$ Uncompromisingly stated, "postmodern thought is undoubtedly part of the modern and not modern thought coming to an end." 47 In van Huyssteen there is a "to-and-fro movement" between modernity and postmodernity, not a unilateral road leading from modernity to postmodernity. As we shall now see, there is even a strong sense of a premodernity living in us and being with us in the form of phylogenetically acquired forms of cognition.

\section{The venue of evolutionary epistemology}

In Duet or Duel? from 1998, the issue of epistemology was also approached from an evolutionary perspective. With evolutionary epistemology, van Huyssteen pointed to the common biological roots of human rationality. These roots may explain, at least in part, the "universal traits" of human reasoning:

Evolutionary epistemology thus reveals the process of evolution as a belief-gaining process, a process that in humans, too, is shaped pre-consciously. All our beliefs, and I would argue, also our religious beliefs, thus have evolutionary origins and were established by mechanisms working reliably in the world of our ancestors. This still does not mean, however, that the theory of evolution by natural selection can offer an adequate explanation for beliefs that far transcend their biological origins. But this again underlines the fact that cognition is a general characteristic of all living beings,

45. Van Huyssteen, The Shaping of Rationality, 150.

46. J. Wentzel van Huyssteen, "Is There a Postmodern Challenge in Theology and Science?” (1997), Essays in Postfoundationalist Theology, 266-79 (279). See also Duet or Duel?, 25-26.

47. J. Wentzel van Huyssteen, "Should We Be Trying So Hard to Be Postmodern? A Response to Drees, Haught, and Yeager," Zygon: Journal of Religion and Science 32(1) (1997): 567-84 (582). 
and that human rationality, therefore, can only be fully understood if its biological roots are understood. ${ }^{48}$

So, while evolutionary epistemology certainly can explain the general trajectories of human reasoning, it cannot explain the particular routes of philosophical and religious traditions, and the particular ways of knowing and arguing within these traditions. For the same reason, particular forms of belief, such as christology and trinitarian belief, or Zen Buddhism, cannot be said to be validated by evolution, even though some of their basic assumptions follow general trajectories honed by evolution.

Van Huyssteen takes a very similar position to the idea of evolutionary ethics. The fact that morality is rooted in our biological make-up as social embodied primates does not mean that particular moral codes can be derived from evolution: "[F]rom the evolutionary genesis of our moral awareness we cannot derive moral codes for right or wrong. Accepting that our moral awareness has evolved also means accepting that our moral codes may not be fixed forever as unchangeable entities." 49 Van Huyssteen thus follows the same kind of reasoning regarding the evolutionary roots of religion and ethics. Just as there is no reason to distrust empathy as a guideline for ethics, there is no a priori reason to distrust the sense of the divine in religion, though we cannot claim that particular ethical or religious systems are simply true by being biologically rooted. Rather, biological evolution facilitates a cultural space for evaluating truth claims and ethical judgment.

If The Shaping of Rationality could be read as an epistemological withdrawal from more substantial interactions between science and theology, Duet or Duel? evidenced that this was far from the author's intention. And soon the transversal concept of interdisciplinary laid out in The Shaping of Rationality was to be applied to the discussion of human origins and human nature. Put in Rescher's terms, "the theoretical cycle" of postfoundationalist epistemology was to be exercised on the material problems in a large scale "applicative cycle" involving paleoanthropology and theological anthropology.

\section{The venue of paleoanthropology}

I am here, of course, referring to van Huyssteen's 2004 Gifford Lectures at Edinburgh University given under the name Are We Alone? Science and Theology on Human Uniqueness, later published under a slightly changed title. ${ }^{50}$

Alone in the World? discusses the species specificity of humanity in close conversation with leading paleoanthropologists and archaeologists, and in more critical interaction with evolutionary cognitive theories of religion. How to speak of

48. Van Huyssteen, Duet or Duel?, 151-52.

49. Van Huyssteen, "Should Theology Take Evolutionary Ethics Seriously?," 282.

50. Van Huyssteen, Alone in the World? Human Uniqueness in Science and Theology. The Gifford Lectures. The University of Edinburgh. Spring 2004. 
humans as created in the image and likeness of God in this context? I guess I am correct in saying that van Huyssteen's book is the only comprehensive book dealing with this subject matter from a theologically informed perspective. Wentzel was alone in creating a fertile space for an interaction between paleoanthropology and theological anthropology.

The point of Alone in the World? is exactly to show how "[t]ransversal lines of argument between evolutionary epistemology and paleoanthropology converge and intersect on the fact that the very first modern humans were distinct in the evolution of their symbolic, cognitive fluid minds." (a term coined by Steven Mithen) which leads to the creative symbolic behavior witnessed in cave art and in the emergence of religious awareness.

With evolutionary epistemology, van Huyssteen understands the human species as a particular form of an information processing system: "[N]ot only has evolution produced cognitive phenomena, but evolution itself can be seen as a cognition process or, more precisely, a cognition-gaining process." ${ }^{52} \mathrm{We}$ are thus still carrying with us earlier instincts (for example, fear of snakes) in a phylogenetic memory that is not in principle different from the snarling of kittens at dogs. ${ }^{53}$ Moreover, this phylogenetic memory must have some adaptive value, also for early humans. Even if not totally correct, such species-wide knowledge has proven overall to be reliable by facilitating appropriate forms of orientation vis-à-vis the environment. Evolutionary epistemologists such as Franz Wuketits admit that human cognition also entails a drive for metaphysical explanation, including notions of another world and life after death. ${ }^{54}$ But curiously enough, Wuketits finds this religious awareness to be fully unreliable, and without any importance for the future development of the human race. Here van Huyssteen raises two questions to Wuketits:

Why should we, so suddenly and only on this point, distrust the phylogenetic memories of our direct ancestors, and why should the emergence of religious consciousness be explained only in terms of specific life-conditions in prehistoric times? Might there not be something about being human, something about the human condition itself, that could offer us a slightly different perspective on the enduring need for religious faith? ${ }^{55}$

Van Huyssteen is fully aware that evolutionary epistemology cannot be used to bolster the correctness of particular religious views, just as it cannot serve as a proof for the reality of God. ${ }^{56} \mathrm{He}$ insists that the space opened by religious awareness, for reasons of consistency, should be treated fully on a par with other

\footnotetext{
51. Ibid., 212.

52. Ibid., 87.

53. Ibid., 84 .

54. Ibid., 94.

55. Ibid., 218.

56. Ibid., 102-109.
} 
outcomes of evolutionarily evolved cognition, and also by evolutionary epistemologists. As a matter of fact, the questioning of the material limitations of human existence seems to be species-specific to humanity.

Moreover, central to evolutionary epistemology is its interactionist orientation. ${ }^{57}$ The adaptations of early humans to their environments gave rise to an intra-organismic development, not least evidenced in the development of the prefrontal cortex, and in the particular array of human uses of our flexible brains. But the process also goes the other way around: the shaping of rationality through adaptive evolution is accompanied by the constructive shaping of the environment by human communities, building up external niches for human communities in a gradual move from natural habitats to sociocultural homes, including also religious traditions.

I cannot but note that van Huyssteen's program here seems closely akin to later work done at Harvard University on the idea of deep history, in which also the traditional divide between historical time and prehistory evaporates. ${ }^{58}$ Both Daniel Lord Smail and Wentzel van Huyssteen understand human personhood and community formation from an interactionist perspective that focuses on human agency as embodied in its relationships to ecological environments, constantly remolded by human intervention, and guided by the use of symbolic thought unique to the human species. As a result, we may not be so vastly different from our forebears. As van Huyssteen notes, the Cro-Magnons of the Upper Paleolithic were, in a sense, "us.", 59

From a methodological perspective, this interactionist view of biological and cultural evolution differs from the fixed view understanding of the human mind that one finds in some proponents of evolutionary cognitive theory of religion. Pascal Boyer, for example, presupposes that the human mind works as a semiautomatic machine, restlessly generating foreseeable outputs in reaction to minimal inputs. Concepts of God, for example, are generated by a "Hyperactive Agency Detection Device" (HAAD), which comes up spontaneously when humans are confronted with fear. According to Steven Mithen, by contrast, our minds are evolved through a general intelligence which was later specialized, until it reached the level of cognitive fluidity: the symbolic threshold. In this view we are embodied beings with flexible minds, capable of exercising a broad array of self-reflective capacities. Art, morality, and religion are thus to be seen as typical expressions of the human mind. Accordingly, human symbolic behavior cannot be divided into

57. Towards the end of Alone in the World? (p. 276), Maurice Merleau-Ponty's "phenomenology of the flesh" is quoted: "I cannot understand the function of the living body except by enacting it myself, and except in so far as I am a body which rises towards the world" (Maurice MerleauPonty, Phenomenology of Perception, trans. Donald A. Landes [London: Routledge and K. Paul, 1962; French original, 1945]), 75.

58. Daniel Lord Smail, On Deep History and the Brain (Berkeley: California University Press, 2006); Deep History: The Architecture of Past and Present, ed. Andrew Shyrock and Daniel Lord Smail (Berkeley: University of California, 2011).

59. Alone in the World?, 218. 
constructs of a natural "agency detection device" versus a "hyperactive" one. Similarly, ritual behaviors cannot be categorized into too clear-cut distinctions between what is useful, or adaptive, in a mundane sense, and what is more than useful, such as play and religious imagination. While van Huyssteen agrees with evolutionary psychology that there is a "naturalness" to religious imagination, he insists that naturalness is not the same as pre-reflective automaticity. There is no reason to believe that the religious mentality of early humans was devoid of selfreflection. ${ }^{60}$ Religious imagination is thus a "natural" propensity, using the same neuronal structures and the same cognitive fluidity as in tool construction, in the planning of a hunt, in the moral ordering of social systems, or in the production of art and deliberate burial sites, showing the vital importance of religious imagination for Neolithic communities. ${ }^{61}$

Of special interest to van Huyssteen's project is what Ian Tattersal has called the "cultural exploration" from 60,000 to 30,000 years ago. Here we find new expressions of art and other expressions of a symbolic awareness that seem to go beyond the realm of the visible. Van Huyssteen is well aware that archeological findings and paleoanthropological material are open for interpretation. Any paleoanthropologist needs to muse on the meanings of the findings, and to make inferences as to the best explanation of the available data. Could we have flutes without ritualized dancing? Could we have cave paintings without a symbolic meaning that goes beyond mere referential meaning? Could we have burial sites with the heads placed towards the east without having belief in afterlife? The vote of van Huyssteen to these questions is a resounding "No." Do some cave paintings indicate shamanism as an early form of religion, but other sites not? Could we have a symbolic mind prior to the formation of the laryngeal tract, the precondition for complex oral speech? The vote of van Huyssteen to these questions is an emphatic "Yes." From here, he goes on to raise a larger set of new research questions: Which role might the body language of the bipedal walk have had prior to oral language, for sexual exposure, for example? Were our ancestors just imagining the invisible in linguistic forms? Could not perhaps a religious meaning be carried by a deliberate ordering of material structures, as evidenced in Çatalhöyük, where the bodies of the deceased were buried inside the houses, excavated after some time, dismembered, using the skulls as pillars for new houses, while ornamenting other skulls and body remnants? Moreover, are we a species that has discovered God as "praying animals" (Robert W. Jenson), not just by being a species speaking about "the beyond," but a species experiencing being addressed by God? Similarly, what is

60. Ibid., 261-70.

61. On burial sites, see van Huysteen's reflection on Ian Hodder's studies on the understanding of individual selfhood and trans-generational transcendence in the lower Neolithic society of Çatalhöyük (Turkey), "The Historical Self: Memory and Religion at Çatalhöyük," in Religion at Work in a Neolithic Society. Vital Matters, ed. Ian Hodder (Cambridge: Cambridge University, 2014), 109-33 (114-21). 
the relation between early religion and the morality of living together in groups, with rules for food-sharing, kinshipping, and burial sites? ${ }^{62}$

Questions such as these feature centrally in Alone in the World? as well as in the subsequent discussions thereof. Wentzel van Huyssteen is the first to admit the unknowns. ${ }^{63}$ But it is consistent with van Huyssteen's own program that such questions can only be dealt with in an academically responsible manner if one is willing to participate in long-term conversations with the best experts in the field-even though they sometimes disagree. Some argue for a more gradualist approach, others for a more discontinuous development. As argued by van Huyssteen, the distinction between gradualism and discontinuity cannot be kept up rigidly. ${ }^{64}$ There is both a continuity between humans and higher apes, and a discontinuity in the sense that oral speech and symbolic language (and the fluid mind undergirding it) are found only in the surviving human lineage that happens to entail agential and self-reflective persons not quite unlike us. We are, in brief, "alone in the world" in a twofold sense: from a paleoanthropological view, we are alone by being the last remnant of the hominids on planet Earth; from a theological perspective we are alone by "being invited in to a personal relationship with God."65

\section{A trans-generational concept of the imago Dei}

What is important for van Huyssteen's theological project when reinterpreting the biblical symbol of the imago Dei is an understanding of human beings as embodied persons endowed with symbolic awareness. ${ }^{66}$ Van Huyssteen makes a tour de force through the interpretation history of the concept of the imago. Here he is particularly drawn to the view of John Calvin who stated that it may be particularly appropriate to say that humanity is created in the image of God in respect of the human soul but that the image extends also to other aspects of human existence- "there was no part even of the body in which some rays of glory did not shine." ${ }^{67}$ Similarly he's tracking the record of twentieth-century interpretations of the imago in terms of substantive capacities, functional roles, and relational structures, pausing (with his typical sense of humor) to note that Karl Barth once remarked that also laughter and smoking belongs to the proprium of being created

62. Questions of social hierarchy, food-sharing, sexual intercourse, and the possibility of including non-kin in "kinshipping" are central to the program of "deep history."

63. See, in particular, "Response to My Critics" (note 13).

64. Alone in the World?, 199-203.

65. Alone in the World?, 121.

66. As for the evolution of personhood, see J. Wentzel van Huyssteen, "When Were We Persons? Why Hominid Evolution Holds the Key to Embodied Personhood," Neue Zeitschrift für Systematische Theologie und Religionsphilosophie 52(4) (2010): 329-49. On imago Dei and Christology, see "What Makes Us Human? The Interdisciplinary Challenge to Theological Anthropology and Christology," Toronto Journal of Theology 26(2) (2010): 143-60.

67. John Calvin, Institutes of the Christian Religion (1559), 1.15, quoted in Alone in the World?, 111, 131. 
in the image and likeness of God. ${ }^{68}$ In the end, van Huyssteen sides with Wolfhart Pannenberg in his eschatological interpretation of the imago (finally a Lutheran sneaks in!). The point here is that Pannenberg's wider eschatological perspective is able to integrate the substantive, functional, and relational aspects of the imago. Not that the imago is only a matter of a future realization, but that the imago is a task waiting to be realized for any human being. The capacity for being humane is a gift of creation, endowed to the human species, and yet it is a destiny in front of us. ${ }^{69}$

According to Christian anthropology, the full humanity and the true image of God is fully realized in Jesus Christ only (Col 1:15; Heb 2:6-9). Even though van Huyssteen is critical of too eager dogmatic attempts at showing that the imago is only understandable from a trinitarian perspective (as if being a Christian was a matter of having a particular Christian gnosis), he does present a picture of what it means to be a human person, which can best be interpreted as related to an economic understanding of the Father, Son, and Holy Spirit, integrating creation, christology, and the future fulfillment. The symbolic awareness of humans thus allows us to be in discourse with God (both as speaking and as listening), and to be connected to one another in caring relationships, also to our "sister species." In this understanding, the final basis for speaking of a human likeness to God does not lie merely in our possession of some intellectual capacities, but in specific uses of these abilities. ${ }^{70}$ Thus understood, speaking of the imago Dei can't be a descriptive affair only. It must take the form of directive speech, orienting our ways of thinking and informing our modes of action. ${ }^{71}$

\section{Concluding reflections}

Allow me at the end to compare the outcomes of van Huyssteen's theological itinerary with another Gifford lecturer, Bruno Latour, who gave the Lectures in Edinburgh in 2013. In We Have Never Been Modern, Latour argued that we never really managed to believe in the modern idea of a dichotomy of the natural versus the cultural, nor in the early modern idea of a full separation of God and world. ${ }^{72}$ In the vein of van Huyssteen, we could add that if God IS, God cannot be fenced into the domain of the supernatural as opposed to the natural but must be the encompassing reality, the source and matrix of all our natural endowments and

68. Karl Barth, Church Dogmatics III/2 (Edinburgh: T \& T Clark, 1960), 82-83: "What a pity that none of these apologists considers it worthy of mention that man is apparently the only being accustomed to laugh and smoke!," quoted in Alone in the World?, 136.

69. Van Huyssteen, Alone in the World?, 139-44. See also David Fergusson's penetrating questions on anthropocentricism(s), "Are We Alone and Does It Matter?" (in this issue of Theology Today).

70. Van Huyssteen, Alone in the World?, 38, 159-62.

71. Cf. ibid. 161.

72. Bruno Latour, We have Never Been Modern, trans. Catherine Porter (Cambridge, Mass.: Harvard, 1993; French original 1991). 
cultural strivings. If Wentzel van Huyssteen's postfoundationalist epistemologically is basically correct, we have never been purely postmodern. Moreover, if his thesis in Alone in the World? stands (as I believe it will do), we have never been purely premodern either. Also our ancestors will have had small spaces of a "modern" control of their environments, as they have also had aspects of a "postmodern" awareness of fluidity, a sense of the possible. They are "us," and we "them." Alone in the world we may be as a species, but humans have always being living and laughing together, as they have also being weeping, mourning, and hoping together.

\section{Author biography}

Niels Henrik Gregersen is Professor of Systematic Theology at the University of Copenhagen, and a long-term collaborator with J. Wentzel van Huyssteen. Latest publications include Information and the Nature of Reality, edited with Paul Davies (Cambridge University Press, 2014), and Incarnation and the Depths of Creation (Fortress Press, 2015). 